\title{
Assessing Migration and Remittance Status and its Effect on Maize Production in Nepal
}

\author{
Yogendra Acharya ${ }^{1 @}$, Yuganath Ghimire ${ }^{2}$, Namdev Upadhayay ${ }^{1}$ and Bikas Poudel ${ }^{3}$ \\ ${ }^{1}$ Nepal Agricultural Research Council, Singha Durbar Plaza, PO Box 5459 Kathmandu, Nepal; @ : \\ yogendraacharya9@gmail.com, ORCID: https://orcid.org/0000-0002-2447-5217; \\ NU: namdevupadhyay@gmail.com \\ ${ }^{2}$ Socio-economics and Agricultural Policy Research Division, Khumaltar, Lalitpur; ynghimire@ gmail.com \\ ${ }^{3}$ Ministry of Agriculture and Livestock Development, Singha Durbar Kathmandu, Nepal; \\ poudel.bikash1@gmail.com
}

Received 22 Aug 2018, Revised 7Jan 2019, Accepted 2 Feb 2019, Published 28 April 2019

Scientific Editors: Devendera Gauchan, Dinesh Babu Thapa Magar and Krishna Timsina

Copyright $\odot 2019$ NARC. Permits unrestricted use, distribution and reproduction in any medium provided the original work is properly cited.

The authors declare that there is no conflict of interest.

\begin{abstract}
Outmigration has been considered a major issue in agricultural production of Nepal. The study aimed to assess migration and remittance status and its effect on maize production. Altogether 682, both migrated and non-migrated households were selected using proportionate random sampling from six representative districts covering four provinces and all ecological domains of Nepal. Primary data were collected through households' survey and focus group discussion using structured and pretested interview schedule. The results showed that 26 percent of households have at least one member living abroad for a job opportunity. Most of the migration was male-centric and Chitwan district ranked first among study districts on migration status. About 43 percent of households received more than two hundred thousand annually as remittance and mostly they used that money in household consumption followed by education and loan repayment. Around 54 percent of households agreed that they were using remittances in maize farming mainly for purchasing chemical fertilizer and improved seed. The use of remittance income in mechanization such as buying/using of corn sheller and power tiller was comparatively very less. The results showed insignificant maize productivity but the fallow land holdings of the migrated household were significantly higher than non-migrating households. The issue of migration and fallow land holdings in maize has become an emerging concern to development worker and policy makers. Therefore, the introduction of efficient maize production system along with value addition program that linked with market targeting youth manpower is an urgent need for effective utilization of fallow land. Moreover, such opportunity also provides an avenue to the productive investment of remittance.
\end{abstract}

Keywords: Fallow land, Maize farming, Migration, Remittance

\section{सारांश}

नेपालमा बैदेशिक रोजगारी र कृषि उत्पादनको सम्बन्धलाई प्रमुख बिषयको रुपमा हेरिन्छ। बढ़दो श्रमशक्तिको पलायनले नेपालको खाद्यान्न र कृषि क्षेत्र निकै प्रभावित भएको छ। यस अध्ययनले बसाईसराई र विप्रेषणको अवस्था र यसले मकैखेतीमा पारेको प्रभाब मुल्यांकन गर्न खोजिएको छ। जसका लागि नेपालको $४$ प्रदेश र पारिस्थितिक क्षेत्रको प्रतिनिधित्व हुने गरी ६ जिल्लाबाट जम्मा ६६२ घरधुरी छनौट गरिएको थियो। घरधुरी सर्बेक्षण र लक्षित समूह छलफल बिधी प्रयोग गर्दे पूर्व परिक्षण गरिएको प्रश्नावलीबाट प्रारम्भिक तथ्यांकहरु संकलन गरिएको थियो। प्राप्त नतिजाले २६ प्रतिशत घरधुरीमा कम्तीमा एक जना ब्यक्ति रोजगारीको लागी बिदेशीभमि गएको पाइन्छ। जसमा अधिकांश बसाईसराई पुरुष केन्द्रित रहेको पाइएको छ। अध्ययन गरिएको ६ जिल्लामध्ये चितवन जिल्ला बैदेशिक बसाईसराईमा पहिलो स्थानमा रहेको पाइएको छ। करिब $४ ३$ प्रतिशत बसाईसराई भएका घरधुरीले बैदेशिक आम्दानीको रुपमा बार्षिक २ लाखभन्दा बढी विप्रेषण प्राप्त गर्ने गरेको पाइएको छ। प्राप्त विप्रेषणमध्ये घरायसी उपभोगको लागी प्रमुख रुपमा खर्च हुने गरेको र सो पश्चात् शिक्षा र ऋण तिर्न प्रयोग भएको पाइयो। करिब पू $\gamma$ प्रतिशत घरधुरीले प्राप्त हुने विप्रेषणलाई मकैखेतीमा प्रयोग गर्ने गरेको 
पाइयो। तीमध्ये अधिकांशले रासायनिक मलखाद र उन्नत बिउ खरिद गर्न उक्त आम्दानी प्रयोग गर्ने गरेको पाइयो। मेशिनरी औजार प्रयोगमा भने उक्त आम्दानीको प्रयोग न्यून भएको पाइयो। प्राप्त नतिजाले बसाइसराई भएका घरधुरीमा मकैको उत्पादकत्वमा महत्वपुर्ण असर नभए पनि बसाईसराई नभएको घरधुरीमा भन्दा बसाईसराई भएका घरधुरीमा महत्वपुर्ण रुपले बढ़ी जग्गाबाको राख्ने गरेको पाइयो। बैदेशिक बसाईसराई र मकैखेती योग्य जग्गा बाभो राख्ने कुरा विकासकर्मी र नीतिनिर्माण गर्नेहरुको माक चिन्ताको विषय बन्न थालेको छ। तसर्थ, बाभो जमिनको प्रभाबकारी सदुपयोग गर्न यस्तो युवा जनशकि लक्षित मकै उत्पादन प्रणाली तथा मुल्य अभिबृद्धि कार्यकम जसले बजारसँग जोडछ अत्यन्त आवश्यक छ। यसका साथै यस किसिमको अवसरले विप्रेषणलाई उत्पादन मुलक लगानी गर्न बाटो देखाउछ।

\section{INTRODUCTION}

Nepalese economy is an agricultural based economy where migration is common(CBS 2012). Being an agrarian economy, Nepal still receives $32 \%$ of GDP from the agricultural sector. Although agriculture is a major source of livelihood of around two-thirds of people, its nature is still subsistence type (MoF 2018). About 21.6 percent of the population still surviving under the poverty line (NPC 2016). Rural youth are increasingly choosing employment in areas other than agriculture which results in more youth outmigration leaving women, children and old people in villages (ADS 2015). The increasing trend of out-migration and youth reluctance towards farming have caused gradual shifting of the agriculture-based economy of the country to an economy that is based on other sources of income including remittances which ultimately threatening food security and agricultural sector (Gartaula et al 2012).

Maize is the second important staple food crop of Nepal. Nepalese farmers grew maize in 0.90 million hectares of land and harvested 2.30 million tons of maize with the productivity of $2.55 \mathrm{t} / \mathrm{ha}$ in $2016 / 17$ (MoAD 2017). Despite the fact of increasing annual production and productivity of maize, the national requirement is still not sufficient resulting imports of maize to fulfil the deficit demand (MoAD 2017, Prasanna et al 2018). Although the land area, production, and productivity of maize are increasing with a slow rate, the increasing trend of poultry and livestock along with population and household income led to more demand in maize grain (Tripathi et al 2016, MoAD 2017). It is imperative that the current demand and supply of maize should be fulfilled by giving more emphasis on increasing domestic production.

There has been a continuous increase in total remittance income in Nepal. Nepal was the fourth highest remittance recipient, as a share of GDP, among all countries and ranks first among the South Asian Association for Regional Cooperation (SAARC) in 2017 (World Bank 2017). It is a fact that remittance coming from migrant worker to low-income country like Nepal is helping the livelihoods of households. But, at the same time migration becomes a contributing factor to low agricultural production and productivity due to loss of labour force. Unlike this, there has been a positive role of foreign earning to rural farming communities. The need for agricultural inputs would be fulfilled by the use of remittance income (Tuladhar et al 2014). However, the increasing trend of youth migration and dependency on remittance income has created both positive and negative effect on the agricultural sector. Agricultural commercialization is taking a slow pace in Nepal. The low economic return of the agricultural sector has caused the rural population to switch over other occupation than farming. The agricultural sector is still unattractive to the youth and lacks higher profit as a result farming communities are engaged in it as a culture and tradition to sustain daily life rather than to generate higher income. Moreover, the productive labor forces are leaving the farming occupation for another job. Though there are significant inflows of remittance in the country, most of these resources have gone into consumption and loan repayment rather than productivity enhancing sector (Maharjan et al 2013, Thapa and Acharya 2017).Therefore, an understanding of migration and remittance status at the household level can have significant policy implication and can be helpful to gain some insights on channelling remittance in the agricultural sector. 


\section{METHODOLOGY}

\section{Survey Design and Study Area}

This study used proportionate random sampling by selecting six districts namely Dadeldhura, Dang, Chitwan, Lalitpur, Sindhupalchowk and Khotang of Nepal. All six districts were selected based on two major criteria. The first criterion was based on the area with maize production potentiality and government given priority as maize zone and super zone. The next one was based on one political and ecological representation of maize growing district covering five development regions and ecological domains ie, Mid Hill and Terai. Dadeldhura district represents far-western and mid hill; Dang district represents mid-western and Terai; Chitwan district represents center and Terai; Sindhupalchwok and Lalitpur represent center, high hill and mid hill; and lastly Khotang district represents eastern mid hill region of Nepal.

\section{Sample Size, Sampling Procedures, and Statistical Analysis}

Altogether 682 maize growing households were randomly selected from six selected districts of Nepal in 2017. Within each district, two potential maize growing pocket areas were selected purposely in consultation with District Agriculture Development Office (DADO-previously functional) and Prime minister Agriculture Modernization Project (PM-AMP) offices based on maize area, production and productivity status. The primary data were collected through a household survey using a pre-tested interview schedule. Focus group discussion and key informant survey were conducted in each district to supplement the primary information obtained from the study area. Collected data from all districts were entered and analyzed by using statistical package for social science (SPSS V.20) and Microsoft Excel 2010. Descriptive analysis of household migration and remittance status was done through percent, mean and frequency calculation. The effect of household migration on the change of maize productivity and land utilization status were also summarized and analyzed by using t-test. The farmers' opinion regarding the priority sector for remittance expenditure was identified on the basis of their priority to make expenses on different requirements. Scaling technique was used to construct an index for identifying their priority. The following formula was used to determine the index of most prioritize option.

$\mathrm{I}_{\text {prob }}=\sum \mathrm{s}_{\mathrm{i}} \mathrm{f}_{\mathrm{i}}$

Where, Iprob= index value for intensity

$\sum=$ summation

$\mathrm{Si}=$ scale value at ith intensity

$\mathrm{Fi}=$ frequency of the ith intensity

$\mathrm{N}=$ total number of respondent $=\sum \mathrm{fi}$

Where, Iprob = index, $0<\mathrm{I}<1$

As per the value of $I_{\text {prob }}$, farmers' priority for remittance expenditure sector was identified, higher index value denotes higher priority while lowest one denotes least priority.

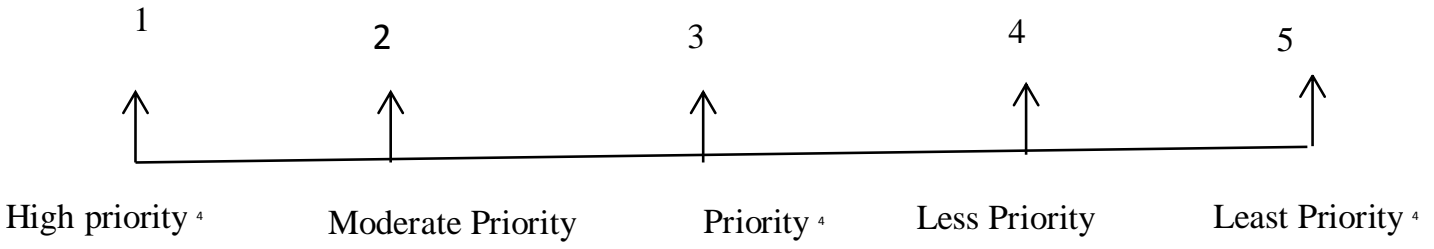

\section{RESULTS}

\section{Migration Status of Study Area}

The information of responding households in terms of migration status are presented in Table 1.The study of six district sample households showed that 26 percent of households have at least one member living outside the country for an employment opportunity. According to the gender perspective, most of the migration was male-centric as about 94 percent of households were male migrated household. Only 
three percent of households were female migrated households while four percent of households had joint migration status i.e. both male and female.

Table 1. Migration status

\begin{tabular}{lcc}
\hline Particulars & $\begin{array}{c}\text { Number of } \\
\text { Households }\end{array}$ & Percentage \\
\hline Migrated households & 177 & 26.00 \\
\hline Non-migrated households & 505 & 74.00 \\
\hline Total & 682 & 100.00 \\
\hline Male migrated households only & 165 & 93.22 \\
\hline Female migrated households only & 5 & 2.83 \\
\hline Migrated households (Male and Female) & 7 & 3.95 \\
\hline Total & 177 & 100.00 \\
\hline
\end{tabular}

Similarly, district wise migration status showed that Chitwan district had the highest percentage of households' migration while the Lalitpur district had the lowest among surveyed districts. The district wise migration and non-migration household status in six districts are given in Table 2.

Table 2. District-wise migration status

\begin{tabular}{|c|c|c|c|}
\hline \multirow[t]{2}{*}{ District } & \multicolumn{2}{|c|}{ Households } & \multirow[t]{2}{*}{ Total Households } \\
\hline & Migrated & Non-migrated & \\
\hline Chitwan & $31(32.00)$ & $66(68.00)$ & 97 \\
\hline Dadeldhura & $20(18.20)$ & $90(81.80)$ & 110 \\
\hline Dang & $46(22.20)$ & 97 (67.80) & 143 \\
\hline Khotang & $36(22.70)$ & $74(67.30)$ & 110 \\
\hline Lalitpur & $14(12.60)$ & 97 (87.40) & 111 \\
\hline Sindhupalchowk & $30(27.00)$ & $81(73.00)$ & 111 \\
\hline
\end{tabular}

Figures in parentheses indicate percentage

Likewise, Sindhupalchowk district was ranked second with 27 percent of migrated household followed by Khotang, Dang and Dadeldhura districts. Among surveyed districts, Lalitpur district had the lowest percent $(12.6 \%)$ of migrated households. Regarding Lalitpur district, lowest migration status among surveyed districts could be due to increased access to employment opportunity as the district is geographically close with capital city Kathmandu. The country like Qatar, UAE and Malaysia were major destinations for migrant households to migrate abroad for an employment opportunity.

\section{Annual Remittance Received}

The income earned by migrant worker varies according to the nature of the host country, nature of job and efficiency of the workforce. For developing countries, remittance inflow has a significant effect on its economy. However, the size of the remittance inflows differs from country to country. Although some of the migrant workers sent a large amount of remittance back home, the average range they sent in Nepal is more or less similar. To depict the range of remittance being received by surveyed households, three groups of the category were constructed as per the preliminary survey. These groups include household with less than a lakh (1 lakh rupees equal to one hundred thousand), one to two lakh and more than two lakh per annum.

Table 3. Breakdown of households by annual remittance received

\begin{tabular}{lcc}
\hline Remittance Received & Number of Households & Percentage \\
\hline Less than 1 lakh & 39 & 22.4 \\
\hline 1-2 lakh & 60 & 34.5 \\
\hline More than 2 lakh & 75 & 43.1 \\
\hline TOTAL & 174 & 100.00 \\
\hline Mean & 2.21 & \\
\hline Std. Dev & 0.785 &
\end{tabular}


Table 3 summarizes the annual remittance received by studied households in six districts of Nepal. Among remittance received households, about 43 percent of households used to receive more than 2 lakh rupees annually as remittance from a foreign country. About 35 and 22 percent of household respectively, received (1-2 lakhs) and less than 1 lakh rupees annually as remittance.

\section{Utilization of Remittance Income}

The priority sector for remittance utilization is shown in Table 4. The study over six districts of Nepal about remittance expenditure priority sector revealed that remittances were mostly used for household consumption purpose. The education sector comes second most priority sector where remittances were used. Similarly, remittance incomes were being used for loan repayment as a third important sector followed by agriculture sector and investment in real estate ie, adding household properties.

Table 4. Remittance expenditure sector

\begin{tabular}{lccccccc}
\hline Sector & \multicolumn{9}{c}{ Score/Frequency } & Index Value & \multirow{2}{*}{ Ranking } \\
\cline { 2 - 7 } & $\mathbf{1}$ & $\mathbf{2}$ & $\mathbf{3}$ & $\mathbf{4}$ & $\mathbf{5}$ & & \\
\hline Education & 32 & 60 & 48 & 26 & 8 & 0.694 & Second \\
\hline Household Consumption & 75 & 60 & 28 & 7 & 4 & 0.824 & First \\
\hline Agriculture & 3 & 16 & 59 & 61 & 35 & 0.474 & Fourth \\
\hline Real estate & 15 & 14 & 12 & 46 & 87 & 0.397 & Fifth \\
\hline Loan repayment & 49 & 24 & 27 & 34 & 40 & 0.609 & Third \\
\hline
\end{tabular}

Use of Remittance in Maize Farming

From the information obtained from six districts of Nepal, it was clear that most of the remittance incomes are mostly used for households' consumption purpose leaving less investment in the farming sector. However, among remittance-receiving households, study results revealed that only 54 percent of households' have used remittance in maize production. About 46 percent of households rejected the chance of using remittance in maize production.

The items for which remittances were used for maize production are listed in Figure 2. The data revealed that among households using remittance in maize production, about 77 and 93 percent of households spent money for improved seed and chemical fertilizer respectively. The data further revealed that the use of remittance in machinery tool is very less; about 14 percent of households spent their remittance income for corn sheller and tractor/power tiller application in maize production.

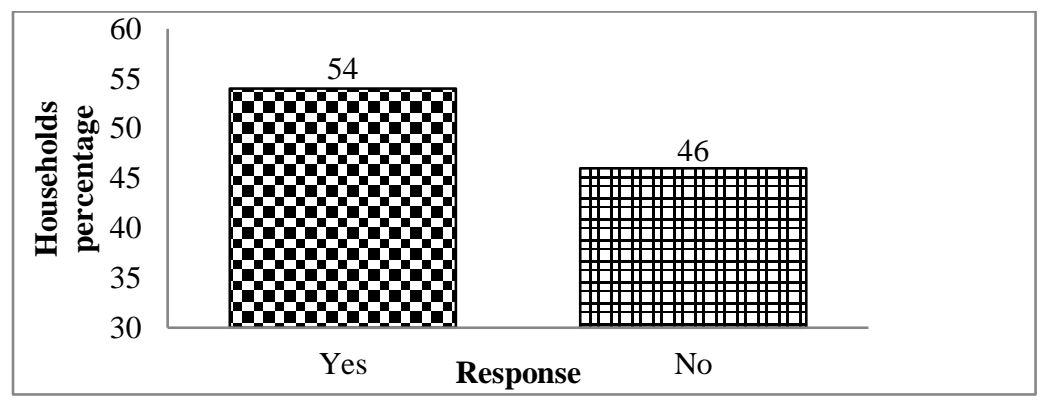

Figure 1. Percentage of households using remittance income in maize production. 


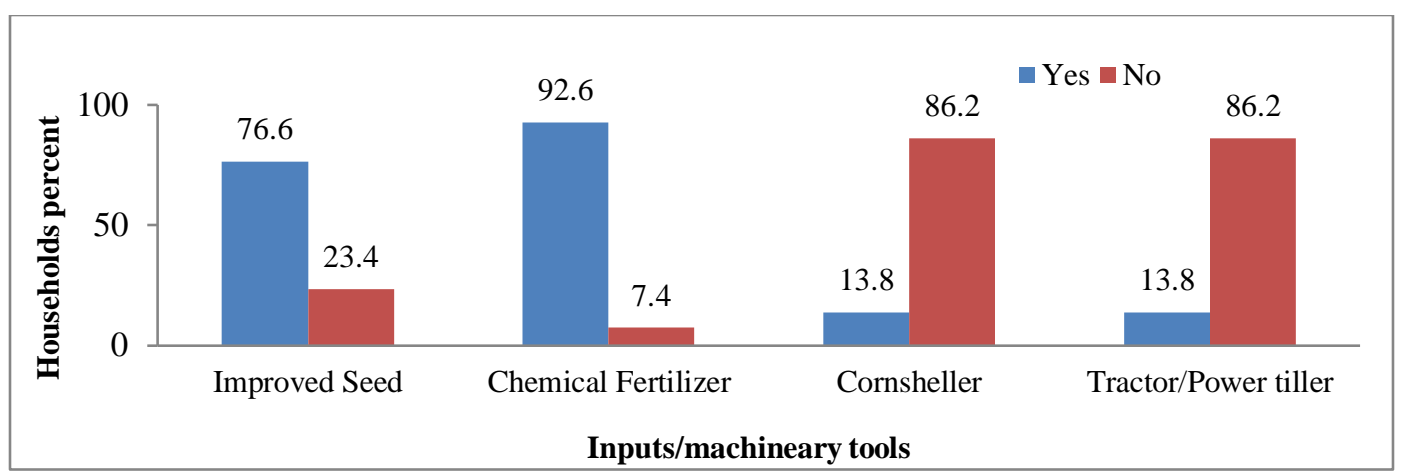

Figure 2. Use of remittance in maize production

\section{Maize Productivity and Fallow Land}

As maize is the second most dominating crop after rice, the production and productivity of maize play an important role in the overall agricultural gross domestic product (AGDP). The productivity status of both migrated and non-migrated households is presented in Table 5. The study revealed that mean maize productivity of migrated households was $2.34 \mathrm{t} / \mathrm{ha}$ whereas the productivity of non-migrated household was $2.45 \mathrm{t} / \mathrm{ha}$. Although the mean productivity of maize was found statistically insignificant, the result depicted the productivity status of the migrated household was comparatively less by $0.10 \mathrm{ton} / \mathrm{ha}$ than a non-migrated household.

Table 5. Maize productivity and fallow land status

\begin{tabular}{lccccc}
\hline Variable & Total $(\mathbf{N}=\mathbf{6 8 2})$ & $\begin{array}{c}\text { Migrated } \\
\text { Households } \\
(\mathbf{n = 1 7 7})\end{array}$ & $\begin{array}{c}\text { Non-migrated } \\
\text { Households } \\
(\mathbf{n}=\mathbf{5 0 5})\end{array}$ & MD & t-value \\
\hline Productivity (t/ha) & 2.42 & 2.34 & 2.45 & -0.104 & -0.717 \\
\hline Fallow land (ha/hhs) & 0.026 & 0.051 & 0.017 & 0.034 & $2.59^{* * *}$ \\
\hline
\end{tabular}

***Significant at 1percent level

Similarly, the increasing trend of fallow land becomes a serious problem in migrated households. Table 5 summarizes the status of fallow land among migrated and non-migrated households. The data from all study districts revealed that mean fallow land holding of migrated households was 0.051 hectare per household. The difference between migrated and non-migrated household in term of holding fallow land $(0.034 \mathrm{ha} / \mathrm{hhs})$ in the surveyed district was found to be significant at $1 \%$ level.

\section{DISCUSSION}

In fact, employment opportunity has been considered as an important livelihood option to every people. In developing countries, out-migration from rural communities is a common livelihood strategy (Gray 2009). The trend of migration has significantly increased since 2002 onwards; however, there was a slight decline in migrant number after massive earthquake felt in 2015 (DoFE 2016). The study data indicate that labor migration in all study districts was male-centric; most of the males are more compelled to go abroad as a migrant worker for fulfilling their basic requirements as a livelihood strategy. Also, in the national context, labor migration is primarily a male phenomenon (MoLE 2018). Though two-thirds of the populations are reliant on farming sector, migration has still become a major economic option indicating the poor performance of the overall agriculture sector. Despite the huge potential of the agricultural sector, the nation is still working hard to achieve a convenient environment for benefiting farming communities from the agricultural sector.

Flows of international remittances have been increased tremendously over a decade of time contributing 26.3 percent to the country GDP in 2016/17 (MoF 2018). Although remittances provide direct support to families and helping families to increase their standard of living, a still high portion of remittance incomes are being used in the unproductive sector. From the information about the priority sector for 
utilization of remittance income, it was clear that the agricultural sector gets the least priority which is supposed to be a worrying factor for country economic growth (Table 4). Investing remittance income in the agricultural sector among remittance-receiving households was found to be the least prioritized sector for farming households. Additionally, it was found that most farmers those who were using remittance income in farming sector simply spent their money on farm inputs. Assessing the maize farmer's preference on remittance use, it depicted that their preference goes to purchasing basic inputs; among them, a majority of households tend to spend more on chemical fertilizer and improved seed (Figure 2). Although there are many reasons behind less preference of farming communities to invest remittance income in maize production, some of the households with remittance shared their experience that they find it optimal to invest remittance income to increase maize production.

Nepalese agricultural sector suffers mostly from low productivity due to labor and credits constraint. A study revealed productivity differences of $0.10 \mathrm{t} / \mathrm{ha}$ between migrated and non-migrated households. Despite the assumption that migrated $\mathrm{HH}$ could have increased productivity of maize due to increased use of farm inputs, it showed a decrease in maize productivity. In the context of labor shortage, another big challenge for Nepalese agriculture is the lack of proper utilization of land resources. Despite having limited cultivable land throughout the country, the trend of keeping farming land as fallow has been growing. Meanwhile, the country is embarking upon increasing food production, but the result revealed that farmers are still holding an average of 0.026 hectares per household land as fallow. Furthermore, information on fallow landholding among migrated and non-migrated households clearly indicates that household with migration status is keeping their more land in fallow condition. A study, conducted in maize dominated mid hill of Nepal revealed that migrating households are abandoning land mainly due to a labor shortage and found that out-migration has played a key role for labor shortage (Jaquet et al 2019).The mean fallow land difference by 0.034 hectares per household could hamper the total maize area of the country significantly (Table 5). Despite government efforts made for agricultural commercialization and development, the issue of leaving land fallow and its consequences to staple food supply has become an emerging concern to stakeholder and policy practitioners. In this regards, policies, and programs that attract youth and remittance income in farming sector are current need to shift remittance-dependent economy to agricultural based economy.

\section{CONCLUSION}

This study assessed the out-migration, remittance and its effect on maize production based on the household survey in six representative districts of Nepal consisting of all five development region and ecological domains. Results obtained from study districts indicate that more than a quarter of households have at least one member out of the house. The pattern of migration is male-centric. Among study districts, Chitwan consists more number of out-migration while out-migration was lower in Lalitpur district which might be due to easy access to the job market within capital city Kathmandu. Further, most of the migrant workers from far western and mid-western region tend to migrate in India. Yet agriculture has been remained as their major occupation, migrating household still considers remittance as a key source of livelihood. The study showed that the majority of migrated households received more than 2 lakhs Nepali rupees annually as income from foreign employment. However, remittances were firstly spent on home consumption purpose followed by education and loan repayment. Investing remittance money in agriculture is the least priority option for most households in the study area. Despite a huge amount of remittance earning, lack of productive use of remittance in agriculture is a matter of concern. It was found that half of the remittances receiving households are using remittance income to buy input and machinery use. Among them, the large majority of households are investing their money for purchasing chemical fertilizers. The yield gap of 0.10 t/ha was identified between migrated and non-migrated households. Similarly, challenges to the agriculture sector have been increasing due to less utilization of available land resources. The analysis of the relationship between fallow land and migration status of households implies that migrated household tends to keep more fallow land resulting in a decrease in the cropping area of the major crop including maize. 
Similarly, findings suggest that remittance income helps in securing livelihood of farming communities in the short run but at the same time decline in productivity and cropping area has raised important concern to policy makers. As given in the result, most of the farmers are investing remittance income for basic inputs like chemicals and seeds, which must be further expanded towards mechanization and basic infrastructure development for enhancing maize production and value addition. Therefore, the introduction of efficient maize production system along with value addition program that linked with market targeting youth manpower is an urgent need for effective utilization of fallow land. Moreover, such opportunity also provides an avenue to the productive investment of remittance.

\section{ACKNOWLEDGEMENTS}

We are very much thankful to SARPOD team for their fulltime supports, suggestions and guidance to finalize this paper. We also extend my gratitude to Dr Sudha Sapkota and Samaya Gairhe, Monitoring and Evaluation Division, NARC for active support and suggestions during paper write up. Appreciation goes to all those farmers, cooperative members, farmer group and DADOs who shared their valuable information and insights while conducting this research.

\section{REFERENCES}

ADS. 2015. Agriculture Development Strategy (ADS) 2015 to 2035. Ministry of Agricultural Development, Singh Durbar, Kathmandu, Nepal.

CBS. 2012. National Population and Housing Census 2011 (National Report). Volume 1, NPHS 2011. Kathmandu, Nepal.

DoFE. 2016. Annual report 2015/16. Department of Foreign Employment, Ministry of Labour and Employment, Buddhanagar, Kathmandu.

Gray CL. 2009. Rural out-migration and smallholder agriculture in the southern Ecuadorian Andes. Population and Environment. 30 (4-5):193-217. DOI:10.1007/s11111-009-0081-5

Gartaula H, A Niehof and L Visser. 2012. Shifting perceptions of food security and land in the context of labour outmigration in rural Nepal. Food Security. 4(2):181-194. DOI:10.1007/s12571-012-0190-3

Jaquet S, T Kohler and G Schwilch. 2019. Labour Migration in the Middle Hills of Nepal: Consequences on Land Management Strategies. Sustainability. 11(5):1349.

Maharjan A, S Bauer and B Knerr. 2013. International Migration, Remittances and Subsistence Farming: Evidence from Nepal: International migration, remittances and subsistence farming. International Migration. 51:e249e263. DOI: 10.1111/j.1468-2435.2012.00767.x

MoAD. 2017. Statistical Information on Nepalese Agriculture (2015/16). Monitoring, Evaluation and Statistics Division, Ministry of Agricultural Development, Singh Durbar, Kathmandu, Nepal.

MoF. 2018. Economic Survey, Fiscal year 2016/17. Ministry of Finance, Singh Durbar, Kathmandu Nepal.

MoLE. 2018. Labour migration for employment. A status report for Nepal: 2015/2016-2016/2017. Ministry of Labour and Employment, Kathmandu Nepal.

NPC. 2016. Three year $14^{\text {th }}$ periodic plan, 2073/74 to 2075/2076. National Planning Commission, Singh Darbar, Kathmandu, Nepal; .

Prasanna BM, D Aparna and KK Kaimenyi. 2018. Book of extended summaries: $13^{\text {th }}$ Asian Maize Conference and Expert Consultation on Maize for Food, Feed, Nutrition and Environmental Security. CIMMYT

Thapa S and S Acharya. 2017. Remittances and Household Expenditure in Nepal: Evidence from Cross-Section Data. Economies. 5(2):16. DOI:10.3390/economies5020016

Tripathi MP, J Shrestha and DB Gurung. 2016. Performance evaluation of commercial maize hybrids across diverse Terai environments during the winter season in Nepal. Journal of Maize Research and Development. 2(1):112. DOI: $10.3126 /$ jmrd.v2i1.16210

Tuladhar R, C Sapkota and N Adhikari. 2014. Effects of migration and remittance income on Nepal's agriculture yield.

World Bank. 2017. Migration and remittances, recent development and outlook. Migration and development brief 28.

||-------|||-------|| 